\title{
Connection of Environmental Education with Application of Experiential Teaching Methods: A Case Study from Greece
}

\author{
Marios Koutsoukos ${ }^{1}$, Iosif Fragoulis ${ }^{2} \&$ Euthimios Valkanos ${ }^{3}$ \\ ${ }^{1}$ School of Agriculture, Aristotle University of Thessaloniki, Greece \\ ${ }^{2}$ School of Pedagogical and Technological Education, Heraklion, Greece \\ ${ }^{3}$ Department of Educational and Social Policy, University of Macedonia, Greece \\ Correspondence: Marios Koutsoukos, School of Agriculture, Aristotle University of Thessaloniki, Greece. \\ E-mail: koutsoukos.marios@gmail.com
}

Received: November 4, 2014 Accepted: December 9, 2014 Online Published: March 29, 2015

doi:10.5539/ies.v8n4p23

URL: http://dx.doi.org/10.5539/ies.v8n4p23

\begin{abstract}
The main objective of this case study is to examine secondary education teachers' opinions concerning the connection of environmental education with the use of experiential teaching methods. Exploring whether the application of experiential methods can upgrade the learning procedure, leading to a more holistic approach, the research focuses on certain aspects of today's educational reality in the field of secondary environmental education. Studying a sample of secondary education teachers in Northern Greece, among the research's main findings is teachers' belief that environmental education can play an important role in today's educational reality, as respondents acknowledge that environmental education in secondary schools can serve as a useful tool for integrating environmental values into students' everyday life.
\end{abstract}

Keywords: case study, environmental education, experiential teaching methods, secondary education teachers

\section{Introduction}

Over the past two decades, environmental education has gained significant recognition as theorists worldwide have acknowledged its value, viewing the environment in its entirety including social, political, economic, technological, moral and aesthetic aspects (Palmer \& Neal, 1994; Palmer, 2002). At the same time, the growing environmental awareness illustrates the need for an effective environmental education scheme that would give birth to new ways of thinking (Markaki, 2014). Recently, the role of environmental education has become a much-debated issue and research on environmental education research has highlighted its rapidly expanding size and increasingly diverse nature (Rickinson, 2001).

Environmental education is a lifelong process which uses a broad range of teaching and learning techniques, with emphasis on practical activities and first-hand experience (Palmer \& Neal, 1994). Thus, experiential methods which focus on students' own life experiences and involve a high degree of participation are becoming increasingly common in environmental education (Daskolia, Dimos, \& Kampylis, 2012).

Experiential learning is a process based on the pedagogical principle of "learning by doing" as students acquire knowledge after having experienced or done something new (Kotti, 2008; Fragoulis \& Tsiplakides, 2009). According to Kolb (1984), experiential learning is a holistic process of adaptation to the real world and therefore it encompasses concepts such as creativity, problem solving, decision making and attitude change (Kolb, 1984). Since the first half of the twentieth century, experiential learning has been promoted by influential educators such as John Dewey and Paulo Freire according to whom methods that go beyond traditional lecture and transfer of information can actively engage students making the learning procedure more interesting and appealing (Maloof, 2006).

\section{Connection of Environmental Education and Experiential Teaching Methods}

It is widely accepted that environmental education and experiential teaching methods are very closely connected. Methods, such as case studies, experiments, field exercises, simulations, excursions, debates, projects, role-playing and guided inquiry facilitate the learning procedure and support students in understanding real-world problems (Markaki, 2014). In addition, experiential methods facilitate learners to open up their senses 
to nature and bond with it, to increase their receptivity toward environmental reality (Daskolia, Dimos, \& Kampylis, 2012). Especially in environmental education, any given classroom or school laboratory can become a setting for experiential learning (Wurdinger \& Carlson, 2010). Also, school yards and the surrounding environment can function as a useful setting for many experiential learning experiences. In any case, school yards can be used in a number of different ways, including experiential studies of flora and fauna, gardening, compost production and recycling projects.

According to scholars, connecting environmental education with application of experiential teaching methods is a strategic direction to consider in building a solid lifelong learning system which encourages participation in the learning experience and engages individuals in authentic, real-world experiences (Markaki, 2014; Sandoval \& Bell, 2004; Rickinson, 2001). It is acknowledged that the use of experiential methods in environmental education aims to integrate environmental thinking into students' everyday lives installing them environmental values and encouraging them to acquire a new way of thinking (Kostova, 2000). Moreover, the application of experiential methods in the field of environmental education develops the idea of teachers' and students' collaboration and enhances students' problem solving skills as well as their social skills and scientific literacy.

Learning through experiential practice can become significantly more dynamic as it allows the development of skills such as confidence, independence and students' autonomy and enhances positive attitudes toward learning (Stoller, 2006; Wurdinger \& Carlson, 2010). Thus, students are likely to understand better the natural world and the environmental issues if they work directly with natural phenomena, using their senses to observe and being engaged to experiential learning in order to extend the power of their senses (Markaki, 2014).

It is also acknowledged that how effective a teaching method turns out to be in practice for a certain class is determined by many factors (Nath, 2005) and apparently, the application of each method is evaluated under different learning environments and under various circumstances. In any case, it is widely accepted that in environmental education experiential teaching methods seem to be more appropriate, more effective and more beneficial for students (Maloof, 2006).

Environmental education is currently at the focus of much theoretical and practical scientific interest and concerns about the various environmental problems have brought environmental education to the centre of public debate (Markaki, 2014; Nath, 2009). Worldwide, in secondary education, environmental education is either a focused subject within the sciences or is a part of student interest clubs, integrating knowledge from different subjects around multidimensional environmental issues. In most cases, environmental education is not restricted to in-class lectures, as it also includes experiential activities in school yards, field studies, laboratory experiments and educational excursions.

In Greece, environmental education is not fully incorporated in the school curriculum and environment related issues are infused into the curriculum of several other subjects such as Physics, Chemistry, and Geography and social problems arising from pollution are also presented and discussed in the context of Social and Political Education subject (Goussia-Rizou \& Abeliotis, 2004). Although environmental education programs are taking place each year, there are certain problems considering the incorporation of environmental education in the school curriculum, the lack of environmental syllabus and textbooks and the teachers' lack of appropriate life-long training as far as general environmental issues are concerned (Goussia-Rizou \& Abeliotis, 2004; Markaki, 2014).

During the last years in Greece, there is a growing scientific interest on issues related to environmental education, which has led to an interesting discussion on the place of environmental education in primary and secondary education (Fragoulis \& Tsiplakides, 2009; Daskolia, Dimos, \& Kampylis, 2012; Goussia-Rizou, \& Abeliotis, 2004). However, the research on teachers' opinions concerning the connection of environmental education with the application of experiential teaching methods is relatively limited.

\section{Method}

A combination of qualitative and quantitative methods was used for the purposes of the present research. Firstly, qualitative research was carried out focusing on a thorough study of the main parameters of the issue, aiming to clarify variables used at the quantitative stage of the research (Richie \& Lewis, 2003).

\subsection{Qualitative Research}

More specifically, qualitative structured and semi-structured interviews, which lasted from one to two hours, took place aiming at the clarification of the attitudes and opinions of a relatively small group, consisting of six Secondary Education teachers of various specialties. The interview as a basic research tool was chosen since it examines issues in an in depth manner and provides detailed information as regards personal opinions and 
perceptions leading, in this way, to a kind of understanding not easily achieved using quantitative methods (Robson, 2011).

Primary data were collected between September and October 2013 and six in-depth interviews were held with teachers selected especially for this purpose. The interviews had an average duration of one hour, were tape recorded and the useful conclusions deduced were utilized as auxiliary material for the final definition of the questionnaire which was used at a later step.

\subsection{Quantitative Research}

Thus, at the stage of quantitative research, the questionnaire method was used as it is one of the most widespread and popular research methods for gathering data (Robson, 2011). It should be mentioned that the unit of analysis for the present study were Secondary Education teachers of various specialties (mathematicians, philologists, physicists, language teachers, biologists, agronomists and engineers) selected with the method of convenience sampling (Babbie, 2001). Although the respondents formed a convenience sample, there was an effort to select teachers that were representative of the population. Thus, the sample was formed by 157 teachers of Secondary Education from General and Technical-Vocational High Schools in the prefecture of Central Macedonia.

The questionnaire was developed specifically for the purpose of this case study, based on literature review, the research's main objective and the conclusions of the qualitative interviews. It consisted of fifty five closed answer questions and the respondents' level of agreement or disagreement with statements was assessed using a 5-point Likert-type scale questions (Robson, 2011; Vagias, 2006). The questionnaire was initially pilot-tested in face-to-face sessions with teachers and redefined based on feedback received. The final survey was conducted between November and December 2013 and statistical analysis was carried out using the Statistical Package for Social Sciences (SPSS v.17).

\section{Results}

\subsection{Qualitative Data}

Among the main findings of the qualitative research is teachers' belief that environmental education can play an important role in today's educational reality. Participants in the present case study acknowledge that environmental education in secondary schools can serve as a useful tool for integrating environmental values into students' mentality. Moreover, teachers believe that there is a strong connection of environmental education with experiential methods. In addition, the majority of respondents expressed the opinion that the systematic application of experiential teaching methods for effective learning requires adequately qualified and highly motivated teachers who are able to answer the requirements of experiential teaching.

\subsection{Statistics and Quantitative Data Analysis}

Next, in the phase of quantitative research, the data processing contributed to the formation of the respondents' profile (Table 1). As far as gender is concerned, the majority of teachers were women $(59.2 \%)$ and the average age was 42.3 years. A notable $62.6 \%$ of the respondents were married and $36.8 \%$ of them hold a postgraduate degree (Master). At the time when the present research was conducted, the teachers' average working experience in Secondary Education was 10.2 years and the $66.2 \%$ of them were teaching in schools located in urban areas, while $33.8 \%$ of them were teaching in schools located in rural areas (Table 1).

Table 1. Secondary education teachers' profile

\begin{tabular}{ll}
\hline Men-Women & $40.8 \%-59.2 \%$ \\
Age (average and standard deviation) & $42.3 \pm 7.5$ years \\
Marital status & $62.6 \%$ married \\
Postgraduate degrees (Masters) & $36.8 \%$ \\
Years working in Secondary Education (average) & 10.2 \\
School's area (urban-rural) & $66.2 \%-33.8 \%$ \\
\hline
\end{tabular}

Next, using a five-point Likert-type scale ranging from never to a great deal (Vagias, 2006), teachers were asked to demarcate to what extent they use certain experiential teaching methods. Bearing in mind the conclusions of the qualitative research, the present case study focused on four teaching methods: field exercise, experiment, simulation and role playing. 
Thus, investigating the frequency of use of experiential teaching methods in secondary environmental education, the results showed that among respondents field exercise is used a great deal $(62.4 \%)$ and a moderate amount (28.1\%) (Table 2). Experiment is also a frequently used method, as it is used a great deal (44.6\%), a moderate amount (28.7\%) and occasionally (24.2\%) while only $2.5 \%$ of the respondents use it rarely (Table 2). Simulation seems to be another frequently used experiential method among teachers as it is used a great deal (43.4\%), a moderate amount $(26.1 \%)$ and occasionally $(26.1 \%)$ while a small percentage of teachers $(4.4 \%)$ rarely use it (Table 2). Finally, the teaching method of role playing is used a great deal (31.2\%), a moderate amount $(28.1 \%)$, occasionally $(28.7 \%)$, rarely $(8.9 \%)$ and never $(3.2 \%)$ (Table 2$)$.

Table 2. Frequency of use of experiential teaching methods

\begin{tabular}{ccccccc}
\hline $\begin{array}{c}\text { Experiential } \\
\text { teaching } \\
\text { methods }\end{array}$ & Never & Rarely & Occasionally & $\begin{array}{c}\text { A moderate } \\
\text { amount }\end{array}$ & $\begin{array}{c}\text { A great } \\
\text { deal }\end{array}$ & Total \\
\hline Field exercise & 0 & 0 & 15 & 44 & 98 & 157 \\
& $(0.0 \%)$ & $(0.0 \%)$ & $(9.5 \%)$ & $(28.1 \%)$ & $(62.4 \%)$ & $(100.0 \%)$ \\
Experiment & 0 & 4 & 38 & 45 & 70 & 157 \\
& $(0.0 \%)$ & $(2.5 \%)$ & $(24.2 \%)$ & $(28.7 \%)$ & $(44.6 \%)$ & $(100.0 \%)$ \\
Simulation & 0 & 7 & 41 & 41 & 68 & 157 \\
& $(0.0 \%)$ & $(4.4 \%)$ & $(26.1 \%)$ & $(26.1 \%)$ & $(43.4 \%)$ & $(100.0 \%)$ \\
Role playing & 5 & 14 & 45 & 44 & 49 & 157 \\
& $(3.2 \%)$ & $(8.9 \%)$ & $(28.7 \%)$ & $(28.1 \%)$ & $(31.2 \%)$ & $(100.0 \%)$ \\
\hline
\end{tabular}

Moreover, using a five-point Likert-type scale ranging from strongly agree to strongly disagree (Vagias, 2006), respondents were asked to express their level of agreement or disagreement with four statements concerning environmental education and experiential teaching methods (Table 3). The results indicated that the vast majority of the teachers strongly agree $(63 \%)$ or simply agree $(33.8 \%)$ with the opinion that experiential teaching methods are connected with environmental education while only five persons (3.2\%) express a neutral opinion.

Next, the present case study focused on researching teachers' opinions concerning the statement that experiential teaching methods can upgrade the learning procedure. The vast majority of the respondents (79\%) strongly agree with this statement, $19.1 \%$ of them simply agree while only three teachers $(1.9 \%)$ neither agree nor disagree.

It is widely considered that students in environmental education prefer to be engaged in experiential learning activities. A notable $63.1 \%$ of the respondents strongly agree (Table 3 ) while only a small percentage $(2.4 \%)$ expresses a neutral opinion, neither agreeing nor disagreeing. Next, teachers were asked to express their opinion on whether experiential teaching methods can be applied in most environmental issues. The majority of the respondents strongly agrees $(61.1 \%)$ or simply agrees $(34.5 \%)$ and only $4.4 \%$ of them neither agrees nor disagrees.

Table 3. Level of agreement with certain statements

\begin{tabular}{|c|c|c|c|c|c|c|}
\hline Statement & $\begin{array}{l}\text { Strongly } \\
\text { disagree }\end{array}$ & Disagree & $\begin{array}{l}\text { Neither } \\
\text { agree nor } \\
\text { disagree }\end{array}$ & Agree & $\begin{array}{l}\text { Strongly } \\
\text { agree }\end{array}$ & Total \\
\hline $\begin{array}{l}\text { Experiential teaching methods } \\
\text { are connected with } \\
\text { environmental education }\end{array}$ & $\begin{array}{c}0 \\
(0.0 \%)\end{array}$ & $\begin{array}{c}0 \\
(0.0 \%)\end{array}$ & $\begin{array}{c}5 \\
(3.2 \%)\end{array}$ & $\begin{array}{c}53 \\
(33.8 \%)\end{array}$ & $\begin{array}{c}99 \\
(63 \%)\end{array}$ & $\begin{array}{c}157 \\
(100.0 \%)\end{array}$ \\
\hline $\begin{array}{l}\text { Experiential teaching methods } \\
\text { can upgrade the learning } \\
\text { procedure }\end{array}$ & $\begin{array}{c}0 \\
(0.0 \%)\end{array}$ & $\begin{array}{c}0 \\
(0.0 \%)\end{array}$ & $\begin{array}{c}3 \\
(1.9 \%)\end{array}$ & $\begin{array}{c}30 \\
(19.1 \%)\end{array}$ & $\begin{array}{c}124 \\
(79 \%)\end{array}$ & $\begin{array}{c}157 \\
(100.0 \%)\end{array}$ \\
\hline
\end{tabular}




\begin{tabular}{|c|c|c|c|c|c|c|}
\hline $\begin{array}{l}\text { Students prefer to be taught } \\
\text { environmental issues through } \\
\text { experiential teaching methods }\end{array}$ & $\begin{array}{c}0 \\
(0.0 \%)\end{array}$ & $\begin{array}{c}0 \\
(0.0 \%)\end{array}$ & $\begin{array}{c}4 \\
(2.4 \%)\end{array}$ & $\begin{array}{c}54 \\
(34.5 \%)\end{array}$ & $\begin{array}{c}99 \\
(63.1 \%)\end{array}$ & $\begin{array}{c}157 \\
(100.0 \%)\end{array}$ \\
\hline $\begin{array}{l}\text { Experiential teaching methods } \\
\text { can be applied in most } \\
\text { environmental issues }\end{array}$ & $\begin{array}{c}0 \\
(0.0 \%)\end{array}$ & $\begin{array}{c}0 \\
(0.0 \%)\end{array}$ & $\begin{array}{c}7 \\
(4.4 \%)\end{array}$ & $\begin{array}{c}54 \\
(34.5 \%)\end{array}$ & $\begin{array}{c}96 \\
(61.1 \%)\end{array}$ & $\begin{array}{c}157 \\
(100.0 \%)\end{array}$ \\
\hline
\end{tabular}

\section{Discussion and Conclusions}

Nowadays, in an age of incessantly growing information, environmental education can promote innovative and experiential learning which provokes interest among students and influences at the same time teachers' and students' behavior towards a more environmentally sustainable philosophy (Kostova \& Atasoy, 2008; Maloof, 2006). Bearing in mind that students are at the center of the educational process, the teachers' role is to organize, guide and support the application of experiential methods in order to engage students into a more exciting and motivating learning procedure. It is generally considered that environmental education is not confined to a certain classroom but is a dynamic process which is connected with experiential teaching methods leading to students' personal development, critical thought and experiential learning.

The findings of this research highlight secondary education teachers' opinions concerning the contribution of experiential teaching methods to environmental education. According to teachers themselves, experiential teaching methods are connected with environmental education and their systematic use can upgrade the learning procedure. It seems that field exercise, experiment, simulation and role playing are the most frequently used in secondary education. These methods can be applied in most environmental issues and teachers strongly believe that their students prefer to learn through experiential methods.

As far as practical implications are concerned, this case study offers interesting insights for educational policy makers, school managers, teachers and researchers in the field of environmental education. Although the results of this study cannot be generalized to the larger secondary education teachers' population, the results can still be useful and provide a starting point for future research on various aspects of this issue.

To sum up, the case study presented in this article builds on our understanding of the connection of environmental education with the use of experiential teaching methods. Further research is needed in order to examine in depth the issue and provide a thorough understanding of its various aspects.

\section{Acknowledgments}

The authors would like to thank the 157 participating professors for their cooperation and willingness to respond to the present survey. In addition, the authors would like to thank the editor and the reviewers of this journal for their valuable comments on an earlier version of this manuscript.

\section{References}

Babbie, E. (2001). The Practice of Social Research (9th ed.). Belmont, CA: Wadsworth Thomson.

Daskolia, M., Dimos, A., \& Kampylis, P. (2012). Secondary teachers' conceptions of creative thinking within the context of environmental education. International Journal of Environmental \& Science Education, 7(2), 269-290.

Foladori, G. (2008). A Methodological Proposal for Environmental Education. Canadian, Journal of Environmental Education, 10, 125-140.

Fragoulis, I., \& Tsiplakides, I. (2009). Project-Based Learning in the Teaching of English as A Foreign Language in Greek Primary Schools: From Theory to Practice. English Language Teaching, 2(3), 113-119. http://dx.doi.org/10.5539/elt.v2n3p113

Goussia-Rizou, M., \& Abeliotis, K. (2004). Environmental Education in Secondary Schools in Greece: The Viewpoints of the District Heads of Environmental Education. The Journal of Environmental Education, $5(1), 1-5$.

Kolb, D. A. (1984). Experiential learning: Experience as the source of learning and development. Englewood Cliffs, NJ: Prentice Hall.

Kostova, S., \& Atasoy, E. (2008). Methods of successful learning in environmental education. Journal of Theory and Practice in Education, 4(1), 49-78. 
Kotti, D. (2008). Experiential learning from theory to practice. Adult Education, 13, 35-41 (in Greek).

Maloof, J. (2006). Experience This! The Experiential Approach to Teaching Environmental Issues. Applied Environmental Education and Communication, 5, 193-197. http://dx.doi.org/10.1080/15330150600914743

Markaki, V. (2014). Environmental Education through Inquiry and Technology. Science Education International, 25(1), 86-92.

Nath, B. (2009). Environmental Education and Awareness. EOLLS Publishers.

Palmer, J. (2002). Environmental Education in the 21st Century: Theory, Practice, Progress and Promise. Routledge.

Palmer, J., \& Neal, P. (1994). The Handbook of Environmental Education. Routledge.

Richie, J., \& Lewis, J. (2003). Qualitative Research Practice. A guide for social science students and researchers. London: Sage Publications.

Rickinson, M. (2001). Learners and Learning in Environmental Education: A critical review of the evidence. Environmental Education Research, 7(3), 207-320. http://dx.doi.org/10.1080/13504620120065230

Robson, C. (2011). Real world research (3rd ed.). Chichester: John Wiley \& Sons Ltd.

Sandoval, W. A., \& Bell, P. (2004). Design-based research methods for studying learning in context: Introduction. Educational Psychologist, 39, 199-201. http://dx.doi.org/10.1207/s15326985ep3904_1

Steele, A. (2011). Beyond Contradiction: Exploring the Work of Secondary Science Teachers as They Embed Environmental Education in Curricula. International Journal of Environmental and Science Education, 6(1), $1-22$.

Stoller, F. (2006). Establishing a theoretical foundation for project-based learning in second and foreign language contexts. In G. H. Beckett, \& P. C. Miller (Eds.), Project-Based Second and Foreign Language education: Past, present, and future (pp. 19-40). Greenwich, Connecticut: Information Age Publishing.

Vagias, W. M. (2006). Likert-type scale response anchors. Clemson International Institute for Tourism \& Research Development, Department of Parks, Recreation and Tourism Management. Clemson University.

Valkanos, E., \& Fragoulis, I. (2007). Experiential learning-its place in in-house education and training. Development and Learning in Organizations: An International Journal, 21(5), 21-23. http://dx.doi.org/10.1108/14777280710779454

Valkanos, E., Giossi, S., \& Anastasiadou, S. (2010). Certified Adult Educators' Attitudes towards Continuing Education. Review of European Studies, 2(1), 61-71. http://dx.doi.org/10.5539/res.v2n1p61

Wurdinger, D. D., \& Carlson, J. A. (2010). Teaching for experiential learning: Five approaches that work. Lanham, MD: Rowman \& Littlefield Education.

\section{Copyrights}

Copyright for this article is retained by the author(s), with first publication rights granted to the journal.

This is an open-access article distributed under the terms and conditions of the Creative Commons Attribution license (http://creativecommons.org/licenses/by/3.0/). 